\title{
Corruption in Secondary Schools: Administrative Strategies for Its' Management
}

\author{
Romina Ifeoma Asiyai \\ Department of Educational Management and Foundations, \\ Faculty of Education, Delta State University, Abraka, Nigeria
}

Doi: 10.36941/jesr-2020-0o10

\section{Abstract}

Corruption is one of the global issues impeding systems effectiveness which has permeated the education system in Africa and Nigeria in particular. This study examined corruption in public secondary schools with the purpose of indenting the forms of corruption prevalent, the perpetrators of corruption, the effects of corruption and the administrative strategies for managing corruption in schools. Ex-post facto research design was employed in this qualitative research. The perceptions of 1160 respondents made up of students, teachers and principals were sought by the use of questionnaire. Descriptive and inferential statistics were employed in analysis of data. The results revealed that several forms of corruption were prevalent in secondary schools in the state. The perpetrators of corruption were identified. The effects of corruption showed that it lowers the quality of teaching and learning, lowers the quality of students learning outcomes and dents the public image of the institutions. The study indentified several administrative strategies for curbing corruption in secondary schools as ensuring that teachers are paid good salary commensurate with the standard of living in the society, formation of anti-corruption clubs, proper value re-orientation, character education and by check mating the movement of teachers during school hours. In conclusion, the study recommends that to increase the awareness of students and staff, principals should encourage the formation of anti-corruption clubs and encourage debates and essay writings on corruption related topics in order to help sensitize staff and students about corruption and the evils associated with it.

Keywords: administrative strategies, corruption, curbing, effects, perpetrator

\section{Introduction}

Education is the most powerful instrument for inculcating into citizens of any country good attributes and values for national building. Through education a child's attitude and character is sharpened with the relevant skills, knowledge and competences needed to contribute to social, economic and political development of the society. It is a fundamental human right as everybody has the right to be educated. Education is one of the main drivers of development, be it human, economic or political. Parents rely on the school to assist in molding the character of their children morally, mentally, spiritually, socially and emotionally. In addition education is to help produce individuals who demonstrate positive and sound values of their society. The ability of students to adapt to any environment they find themselves depends on the support they get from their teachers, classmates and principals during the education process. The students' critical thinking, communication and problem solving skills are largely dependent on the kind of education and training they are exposed to in school. The Federal Government of Nigeria (2014) in the National Policy of Education 
recognized education as a pillar for piloting national development. As a result, there can be no development in the country without a formidable and sound system of education. Any society striving for restructuring to align to acceptable international standards must invest hugely in education.

Secondary education in Nigeria is to help individuals live a useful life in the society as well as prepare them for higher education. The individual who passes through secondary education in the country is expected to be able to make useful contribution to the development of the society. It becomes imperative that the education the individual must receive at the secondary level in Nigeria must be of good quality in all ramifications. Good quality secondary education implies that the facilities, infrastructures, information and communication technology facilities, relevant curriculum are procured, and teachers of the right quality and quantity are recruited.

A major issue posing a big challenge to education in Nigeria is corruption. The sting of corruption is hard on the entire Nigerian society and is damaging the education system especially at the secondary level. A society whose educational system is damaged by the plague of corruption would continue to face development challenges. The term corruption has been defined by several authors. Corruption can be seen as the systematic use of public office for personal gain thereby impacting significantly on access to education, equity and quality (Hallak \& Poisson, 2002; Nwankwo \& Nweke, 2016). Transparency International (2010) sees corruption as the abuse of power by individuals to whom is entrusted for personal gain. Every organization has individuals or persons entrusted with the power to coordinate and direct the affairs of the organization. Some of these individuals misuse the power bestowed on them by doing things contrary to that which is expected of them only to their own advantage. These individuals put their personal interest first and surrogate the interest of the organization.

\section{$1.1 \quad$ Statement of the Problem}

Corruption has been one of the major challenges in the administration of education in Nigeria especially at the secondary level. In most discussion stakeholders complain about the rising tide of corruption in secondary education. The sting of corruption in secondary education is biting very hard and has to be checked before it goes out of hand. Students are supposed to learn good morals in school but when the institution is dominated with corrupt practices, students who often copy, emulate and replicate the behaviours of people they meet at school would become endangered. Some studies have been conducted on corruption in secondary education in Nigeria. These studies covered other states like Cross Rivers (Okpechi, Denwigwe, Asuquo, Abuo, Unimna, \& Kolawole2o18), other studies Adebayo and Obaje (2016) corruption and attainment of education objectives and Ugoani (2016) looked at corruption and teacher absenteeism. This study examined corruption in Edo State public secondary schools from different perspective.

\subsection{Specific Objectives of the Study}

The study specific objectives are:

1. To identify the forms of corruption prevalent in public secondary schools in Edo State, Nigeria.

2. To find out the perpetrators of corruption in public secondary schools in Edo State, Nigeria.

3. To ascertain the effects of corruption in secondary education in Edo State, Nigeria.

4. To identify administrative strategies that can be employed to curb corruption in secondary education.

\subsection{Research Questions}

The study provided answers to the following questions: 
1. What are the forms of corruption prevalent in public secondary schools in Edo State, Nigeria?

2. Who are the perpetrators of corruption in public secondary schools in Edo State, Nigeria?

3. What are the effects of corruption in secondary education in Edo State, Nigeria?

4. What administrative strategies can be employed to curb corruption in secondary education in Edo State, Nigeria?

\section{Conceptual Clarification and Literature Review}

The United Nations Convention against Corruption (UNCAC), (2003) sees corruption as an insidious plague having several corrosive effects on nations. Accordingly, UNCAC stressed that corruption undermines the rule of law, quality of life and democratic principles, leads to violation of human rights, threatens human security and distortion of markets. Crime and terrorism abounds in a country where corruption thrives as a life style of the citizens. Every organization has individuals or persons entrusted with the power to coordinate and direct the affairs of the organization. Some of these individuals misuse the power bestowed on them by doing things contrary to that which is expected of them only to their own advantage. These individuals put their personal interest first and surrogate the interest of the organization. Adebanjo (2014) opined that corruption is an immoral and criminal act, a mindset to do wrong and a disposition to exhibit dishonest behaviour by committing an offence against morality, the law and the ethical norms of the society. Corruption has also be seen as the systematic use of public office for personal gain thereby impacting significantly on access to education, equity and quality (Hallak \& Poisson, 2002; Nwankwo \& Nweke, 2016).

Corruption is a global phenomenon which has permeated nations' economies and education system.. In Nigeria the first recorded case of corruption in the education industry took place in 1906 when the primary school certificate examination questions leaked (Asiyai, 200o). Since then corruption has continued to reoccur in the system and penetrated the secondary education level. In Sub Sahara Africa studies abound on corruption. World Bank (2003) reported that in education, more than $67 \%$ respondents expressed that bribery is a part of everyday life. Patrinos and Ruthkagia (2007) cited in Meet and Narayan (2014) noted that teacher absenteeism is a major form of corruption in education system stressing that its effects on students is damaging and destructive. Closely related is the prevalent of ghost teachers, another education corruption that can drain a nation's economy and collapse the education system. Corruption hinders socio-economic growth and good governance (Asongo, 2013; frustrates reduction of poverty (Justesen \& Bjornskov, 2014) and worsens political instability (Favzanegen \& Witthuhn, 2016). A report by Asongo, (2013) noted that nearly 150 million dollars is lost to corruption in Africa on a yearly basis. This money lost ought to have been used to pilot economic development agenda. According to Akande (2017) corruption weakens delivery of public service and leads to misdirection of resources, holding back the growth required to pull people out of poverty. In Kenya, Taaliu (2017) noted that the process of recruitment, promotion and deployment of teachers is mired by corruption in the forms of ethnicity and nepotism. In addition, Taaliu (2017) reported that some principals practice nepotism during admission by admitting their relatives, church members and tribesmen. In Brazil, Ferraz, Finan and Moreira (2012) reported that schools in municipalities where corrupt practices in form of missing resources and bribery were detected had few infrastructural facilities and teachers. In Ramania Baccalaureate high school final examination batches of identical answers to examination questions were distributed to students by teachers, thus encouraging mass cheating (Borcan, Lindahl and Mitrut, 2014). Aduhor (2015) found that ethical challenges confronting secondary school principals in daily school administration were examination malpractices, extortion of money by teachers from students and leakage of examination questions.

In Delta State, the 2013 Mid-Term Report by the Honourable Commissioner for Basic and Secondary Education, Prof. Patrick Muoboghare explained the efforts of the state government to revamp the secondary school education sector in the state by prohibiting illegal collection of levy in 
public secondary schools, closing down some dilapidated schools that were not repaired due to mismanagement of allocated fund (Delta State Ministry of Information, 2013). Five principals in the state were demoted to classroom teachers for professional and financial misconduct and negligence of duty. Two of the principals disregarded the Delta State Ministry of Education directives and took their students to schools in another state to register for external examination. Five students of Zappa mixed secondary school Asaba were suspended for assault on teachers. Others received the hammer for being unable to explain the whereabouts of fifty computers, $25 \mathrm{KVA}$ generating plant in stalled in their schools by the state government (The Premium Times, 2012). As noted by Oyadongha (2013), what is readily observable is that principals are busy extorting money through several illegal charges imposed on students and their parents in their bids to meet the financial resource needs of their schools. Worried about gross corruption in Nigeria, Odeh (2015) decried that not much visible changes have been noticed in the standard of living of citizens.

Although corruption is a global phenomenon, it has to be addressed in Nigerian education system since the products of secondary education are mostly youths who would be future leaders of the country. Fighting corruption at secondary education in the country is the right thing to be pursued by all stakeholders.

\section{Methodology}

This is a descriptive survey research design. The study population comprised 259 public secondary schools in the 18 local government areas of Edo State, Nigeria. Eight out of eighteen local government areas were selected through the use of purposive simple random sampling technique. The use of this sampling technique was because of the difficulty of covering the entire population. Through this sampling technique, sample of 1160 respondents from secondary schools in the eight local government areas were selected. The breakdown of the sample is principals $(n=80)$, teachers $(n=$ $600)$, parents $(n=300)$ and students $(n=180)$.

\subsection{Instrument for Collection of Data}

Data for the study was collected through the use of structured questionnaire which comprised of five sections. The first section comprised of demographic data of the respondents. The second section contained 14 items in forms of corruption prevalent in secondary schools in Edo State. The third section contained 10 items on perpetrators of corruption in secondary schools. The fourth section contained 8 items on the effects of corruption in secondary education. The fifth section contained 8 items on the administrative strategies for curbing corruption in secondary education responded to by principals, teachers and parents.

\subsection{Validity Determination}

The content validity of the instrument was carried out by two experts in educational administration who are Professors in the Department of Educational Management and Foundations of Delta State University, Abraka. The content validity was determined by reading through each item and modifying those they found not suitable. Seven items that did not measure what they intended to measure were deleted. Based on their advice after thoroughly scrutinizing the instrument the correction they suggested were used to bear on the items before the final draft was produced.

\subsection{Reliability Determination}

Split half technique was employed in reliability determination of the instrument. This technique is concerned with determining the internal consistency of the instrument. The instrument was administered to thirty respondents in secondary schools in Edo State that were not included in the 
study sample. The items were then subdivided into two halves on odd- and even- number basis. The scores of all the odd items were summed up as a group (X), while the scores of all the even items were summed up as another group (Y). The two groups of scores were correlated, using Pearson Product Moment formula. The reliability index obtained was stepped up using Spearman Brown Prophesy Formula to obtain reliability indexes of $0.74,0.77,0.75,0.72$, and 0.76 .

\section{Results}

Table 1: Identified forms of corruption prevalent in secondary education in Nigeria

\begin{tabular}{|c|l|c|c|c|c|}
\hline \multirow{2}{*}{ S/N } & \multirow{2}{*}{ Statement } & \multicolumn{2}{|c|}{ Yes } & \multicolumn{2}{c|}{ No } \\
\cline { 3 - 6 } & & $\mathbf{N}$ & $\mathbf{9}$ & $\mathbf{N}$ & $\mathbf{0}$ \\
\hline 1 & Collection of gifts & 690 & 61.06 & 440 & 38.94 \\
\hline 2 & Recruitment corruption & 896 & 79.29 & 234 & 20.71 \\
\hline 3 & Extortion of money from students & 840 & 74.34 & 290 & 25.66 \\
\hline 4 & Illegal charges by principals & 920 & 81.42 & 210 & 18.58 \\
\hline 5 & Absenteeism by teachers & 720 & 63.72 & 410 & 36.28 \\
\hline 6 & Collection of kickbacks from contractors & 805 & 71.24 & 325 & 28.76 \\
\hline 7 & Bribing for admission into federal schools & 668 & 59.12 & 462 & 40.88 \\
\hline 8 & Registration corruption & 890 & 78.76 & 240 & 21.24 \\
\hline 9 & Keeping files of ghost staff & 628 & 55.58 & 502 & 44.42 \\
\hline 10 & Concealing information & 540 & 47.79 & 590 & 52.21 \\
\hline 11 & Favouritism in admission & 789 & 69.82 & 341 & 30.18 \\
\hline 12 & Irregular movement during school hours & 786 & 69.56 & 344 & 30.44 \\
\hline 13 & Withholding of books allocated to schools & 840 & 74.34 & 290 & 25.66 \\
\hline 14 & Examination malpractices & 958 & 84.78 & 172 & 15.22 \\
\hline
\end{tabular}

From Table 1 , the forms of corruption in secondary education in Nigeria are examination malpractice (84.78\%), illegal charges by principals $(81.42 \%)$, recruitment corruption (79.29\%), registration for external examination corruption $(78.76 \%)$, extortion of money from students and withholding of books allocated to schools (74.34\%), collection of kickbacks from contractors (71.24\%), favouritism $(69.82 \%)$, irregular movement of teachers during school hours $(69.56 \%)$, absenteeism by teachers $(63.72 \%)$, and collection of gifts from students (61.06\%), bribing for admission into federal government schools $(59 \cdot 12 \%)$, and keeping files of ghost staff $(55.58 \%)$.

Table 2: Percentage analysis of respondents views on perpetrators of corruption in secondary education in Edo State, Nigeria

\begin{tabular}{|c|l|c|c|c|c|}
\hline \multirow{2}{*}{ S/N } & \multirow{2}{*}{ Statement } & \multicolumn{2}{|c|}{ Yes } & \multicolumn{2}{c|}{ No } \\
\cline { 3 - 6 } & & $\mathbf{N}$ & $\mathbf{9}$ & $\mathbf{N}$ & $\mathbf{0}$ \\
\hline $\mathbf{1}$ & Principals & 915 & 80.97 & 215 & 19.03 \\
\hline $\mathbf{2}$ & Contractors & 745 & 65.93 & 385 & 34.07 \\
\hline 3 & Students & 850 & 75.22 & 280 & $\mathbf{2 4 . 7 8}$ \\
\hline 4 & Parents & 690 & 61.06 & 440 & 38.94 \\
\hline 5 & Teachers & 770 & 68.14 & 360 & 31.86 \\
\hline 6 & Inspectors & 650 & 57.52 & 480 & 42.48 \\
\hline 7 & Ministry of Education officials & 870 & 76.99 & 260 & 23.01 \\
\hline 8 & External Examiners & 900 & 79.65 & 230 & 20.35 \\
\hline 9 & Invigilators & 736 & 65.13 & 394 & 34.87 \\
\hline 10 & Supervisors & 787 & 69.65 & 343 & 30.35 \\
\hline
\end{tabular}

Table 2 shows the views of respondents on the perpetrators of corruption in secondary education in 
Edo State, Nigeria. From the information provided in the Table 2, majority of the respondents (80.97\%) said that principals perpetrate corruption, $79.65 \%$ of respondents said external examiners are perpetrators of corruption. $75.22 \%$ responded positively that students are perpetrators of corruption. $69.65 \%$ said supervisors are perpetrators of corruption.. $68.14 \%$ of the respondents said corruption is perpetrated by teachers. $65.93 \%$ responded that contractors are perpetrators of corruption. And $65.13 \%$ said invigilators are perpetrators of corruption. This information is presented in a bar chart represented as fig 2 .

Table 3: Percentage Analysis of Respondents Views on Effects of Corruption in secondary education in Nigeria

\begin{tabular}{|c|l|c|c|c|c|}
\hline \multirow{2}{*}{$\mathbf{S} / \mathbf{N}$} & \multirow{2}{*}{ Statement } & \multicolumn{2}{|c|}{ Yes } & \multicolumn{2}{c|}{ No } \\
\cline { 3 - 6 } & & $\mathbf{N}$ & $\mathbf{0}$ & $\mathbf{N}$ & $\mathbf{\%}$ \\
\hline $\mathbf{1}$ & Dropout & 720 & 63.72 & 410 & 36.28 \\
\hline $\mathbf{2}$ & Inequality & 750 & 66.37 & 380 & 33.63 \\
\hline 3 & Lowers quality of teaching & $\mathbf{1 1 0 0}$ & 97.35 & 30 & $\mathbf{2 . 6 5}$ \\
\hline 4 & Stalled development & 820 & 72.57 & 310 & $\mathbf{2 7 . 4 3}$ \\
\hline 5 & Overstaffing & 860 & 76.11 & $\mathbf{2 7 0}$ & $\mathbf{2 3 . 8 9}$ \\
\hline 6 & Understaffing & 820 & 72.57 & 310 & $\mathbf{2 7 . 4 3}$ \\
\hline 7 & Lower quality of students' outcome & 870 & 76.99 & $\mathbf{2 6 0}$ & $\mathbf{2 3 . 0 1}$ \\
\hline 8 & Poor global image & 868 & 76.81 & $\mathbf{2 6 2}$ & $\mathbf{2 3 . 1 9}$ \\
\hline
\end{tabular}

Data presented in Table 3 indicates that $97.35 \%$ of respondents said that corruption lowers the quality of teaching and learning. $76.99 \%$ of respondents said that corruption lowers the quality of students learning outcomes. $76.81 \%$ of respondents said that corruption results in poor global image of the education system, $76.11 \%, 72.57 \%$ and $72.57 \%$ of respondents said that corruption leads to overstaffing of some schools, understaffing of some schools and a stall in development respectively. $63.72 \%$ of respondents expressed that corruption can lead to drop out from school and $66.37 \%$ of the respondents said that corruption can result to inequality. This information is presented in a bar chart below.

Table 4a: Summary of ANOVA Analysis on Administrative Strategies for Curbing Corruption in Secondary Education

\begin{tabular}{lccccc}
\hline Variables & Sum of Squares & Mean Square & Df & F-Cal & Sig \\
Between Groups & 193.489 & 96.744 & 2 & 343.613 & ooo \\
Within Groups & 266.629 & .282 & 7 & & \\
Total & 460.118 & & 949 & & \\
\hline
\end{tabular}

The f-calculated value of 343.613 is significant at $\mathrm{df} 2,7 / 949$ and 0.05 level of significance. The null hypothesis earlier stated is not acceptable. This means that there is a significant difference among the three groups on the strategies for curbing corruption in secondary education in Edo State, Nigeria. To find out where lays the difference, Tukey HSD ANOVA analysis is computed. 
Table 4b: Summary of Tukey HSD ANOVA analysis on administrative strategies for curbing corruption in secondary education in Nigeria

Multiple Comparisons

Dependent Variable: Administrative Strategies for Curbing Corruption in Secondary Schools Tukey HSD

\begin{tabular}{|c|c|c|c|c|c|c|}
\hline \multirow{2}{*}{ (I) Personnel } & \multirow{2}{*}{ (J) Personnel } & \multirow{2}{*}{ Mean Difference (I-J) } & \multirow{2}{*}{ Std. Error } & \multirow{2}{*}{ Sig. } & \multicolumn{2}{|c|}{$95 \%$ Confidence Interval } \\
\hline & & & & & Lower Bound & Upper Bound \\
\hline \multirow{2}{*}{ Parents } & Principals & .11767 & .08105 & .315 & -.0726 & .3079 \\
\hline & Teachers & $-.91733^{*}$ & .03752 & .000 & -1.0054 & -.8293 \\
\hline \multirow{2}{*}{ Principals } & Parents & -.11767 & .08105 & .315 & -.3079 & .0726 \\
\hline & Teachers & $-1.03500^{*}$ & .07810 & .000 & -1.2183 & -.8517 \\
\hline \multirow{2}{*}{ Teachers } & Parents & $.91733^{*}$ & .03752 & .000 & .8293 & 1.0054 \\
\hline & Principals & $1.03500 *$ & .07810 & .000 & .8517 & 1.2183 \\
\hline
\end{tabular}

*. The mean difference is significant at the o.05 level.

Table 4c: Administrative strategies for curbing corruption in Secondary schools in Nigeria

\begin{tabular}{|l|c|c|c|c|c|c|c|c|}
\hline \multirow{2}{*}{ Variables } & \multirow{2}{*}{$\mathrm{N}$} & Mean & \multirow{2}{*}{$\begin{array}{c}\text { Std } \\
\text { Dev }\end{array}$} & \multirow{2}{*}{$\begin{array}{c}\text { Std } \\
\text { Error }\end{array}$} & $\begin{array}{c}\text { L5\% Confidence Interval } \\
\text { Bound }\end{array}$ & $\begin{array}{c}\text { Upper } \\
\text { Bound }\end{array}$ & \multirow{2}{*}{ Minimum } & \multirow{2}{*}{ Maximum } \\
\hline Parents & 300 & 2.6317 & .71872 & .04150 & 2.5500 & 2.7133 & 1.10 & 4.00 \\
\hline Principals & 50 & 2.5140 & .42234 & .05973 & 2.3940 & 2.6340 & 1.50 & 3.40 \\
\hline Teachers & 600 & 3.5490 & .41556 & .01697 & 3.5157 & 3.5823 & 1.20 & 4.00 \\
\hline Total & 950 & 3.2048 & .69631 & .02259 & 3.1605 & 3.2492 & 1.10 & 4.00 \\
\hline
\end{tabular}

From Table $4 \mathrm{a}, 4 \mathrm{~b}$ and $4 \mathrm{c}$ one way analysis of variance between the three groups indicated there was a statistical significant difference at $\mathrm{p}<0.05$ level, $\{\mathrm{F}(2,949) 343.613, \mathrm{p}=0.000\}$. Post-hoc comparisons using the Tukey HSD test indicated that the mean score for group $1(\mathrm{M}=\mathbf{2} .6317$, Std $\mathrm{Dev}=0.71872)$ was statistically different from group 3 ( $M=3.52$, Std Dev=0.42234). Group $2(M=2.5140$, Std $D e v=0.41556)$ did not statistically differ significantly from either group 1 or group 3.

\section{Discussion}

The findings of this study in Table 1 and Fig rrevealed the several forms of corruption prevalent in secondary schools in Edo State, Nigeria. The order of prevalent corruption is examination malpractice, collection of illegal charges by principals, recruitment, extortion of money by teachers and with holding of text books allocated to schools, favouritism, irregular movement of teachers during school hours and admission bribery. The finding agrees with Whawo (2015) that secondary schools in Delta State examination malpractice, bribery, nepotism during admission and extortion of money from students in order to get undeserved grades were among the forms of corruption. The finding of this study also lend credence with Taaliu (2017) who reported that in Kenya, the process of recruitment, promotion and deployment of teachers is mired by corruption in the forms of ethnicity and nepotism and that during admission, some principals by admitting their relatives, church members and tribesmen practice corruption. The finding also supported by Amini-Philips \& Chukwuma (2017) who found that extortion of money by lecturer, cheating in examination and bribery where forms of corruption. In addition, the finding is similar to that of Choe, Dzhumashev, Islam, and Khan (2013) they reported increased incidence of corruption in Bangladesh through payment of bribe by people of higher social class who bypass the red tape. Similar finding by Okpechi, et al (2018) indicated high prevalence of corruption among adolescents in Calabar, Nigeria. 
When school principals and teachers collect money from students few days before external examination begins, they turn blind eyes on the students and allow them to copy from text books or from each other. Some of the teachers even tip off external supervisors and write answers to examination questions on the white board for students to copy. This situation is dangerous for the students who are future leaders of tomorrow. Corruption puts students from poor family at a disadvantage as they are unable to pay money demanded from teachers for better grades. Some of these students suffer bitterly in the hands of some teachers and get frustrated and eventually drop out from school. Some teachers come to school early in the morning, clock in their names in the biometric capture machine and disappear to their personal business and return back to school at closing time to clock out. This situation is very bad because the syllabus will not be covered and students will be left with little or no knowledge of the contents of the subjects. In addition parents are supposed to be character builders of their children and families for nation building. But they encourage corruption by taking their children and wards away from their original school to schools noted as "miracle centres" to enroll them for external examinations then curbing the dilemma of corruption becomes difficult. Even ministry of education officials and chief inspectors of education often pressurize school heads to remit money to them. The only option is for the school heads to levy illegal charges on students. In the past students use to carry out crafts as hand work. But in the present situation public secondary school students in Nigeria no longer participate in hand works. School heads levy charges on them which they pay as hand works. The money collected a particular percentage is remitted to chief inspectors of education and ministry of education officials.

In answer to research question 2, the result of this study shown in Table 2 and fig 2 indicated the perpetrators of corruption in secondary schools in Edo State, Nigeria. Principals are key perpetrators of corruption and they collect illegal charges from parents and their children. This finding agrees with that of Whawo (2015) who found that students, teachers and other staff of secondary schools in Delta State, Nigeria indulge in corrupt practices. The finding corroborates that of Ogbonnaya (2009) that ministry officials collected bribe from contractors handling building projects in schools. In addition, the finding lend credence with Babalola (2010) who found that teachers demanded for gratification from students and that this situation has lead to decline in the standard of education. When fund budgeted and allocated to schools for proper management are diverted by ministry of education officials, this can lead to non maintenance of schools and non purchase of instructional materials for effective students' learning. The classrooms will be overcrowded and activities will crumble.

For research question 3 the result shown in Table 3 and Figure 3 indicates that corruption in secondary education lowers the quality of teaching and learning and the quality of students learning outcomes, result in poor global image of the education system, leads to overstaffing and understaffing of some schools, a stall in development, drop out from school and can result to inequality. This finding corroborates that of Ferraz, Finan \& Moreira (2012who found decline in academic performance of primary school pupils in Brazil and increased dropout rates in municipalities where corruption was prevalent. In addition, the finding agreed with that of Olatunde. \& Obaje. (2016) that corruption jeopardized the realizations of objectives of education at the basic level. Appointment of teachers by taking bribe and appointment of under qualified teachers or appointing teachers who do not have a teaching certificate will spell doom for delivery of quality teaching and learning. These non professional teachers do not even know the philosophy of education and teaching methodologies. The cumulative effect is poor delivery, limited access to education and low students' outcomes. In Delta State for example, registration of senior secondary year three students for external examinations like WAEC and NECO are free but some principals impose illegal charges on parents and tag it different names. The effects or consequences of corruption are long lasting, spreading into several generations. The young citizens of the country are made to believe that the best way of making it in life is through short cuts by bribery, nepotism, and favouritism . There is this slogan they popularly say "use what you have to get what you want". Important core morally acceptable values such as trust, hard work, responsibility, honesty, integrity, 
respect, due process and commitment have been jettisoned because of corruption. The ultimate strength of a nation lies in the moral and ethical foundation of the citizens and its' economic competitiveness but because of corruption in Nigeria the strength of the nation is weak.

For research question four, the findings showed that corruption in secondary education can be controlled by applying some administrative strategies including prompt payment of teachers' salaries, ensuring that teachers are paid good salary commensurate with the standard of living in the society, formation of anti-corruption clubs, proper value re-orientation, character education and by check mating the movement of teachers during school hours. Corruption in secondary schools must be curbed. A complete value re-orientation is a best practice that can be adopted in order to successfully address corruption in secondary schools in Nigeria. The teaching of moral values acceptable by the society will be the right option in the present situation to help re-direct Nigerian youths on the right way. This find corroborates that of Augusto (2014) who noted that with appropriate compensation of civil servants they would be motivated to improve performance and productivity.

\section{Conclusion}

The conclusion drawn from this study is that several forms of corruption are prevalent in secondary schools in Edo State, Nigeria Some stake holders in secondary education perpetrate corruption. Corruption in secondary school impacts negatively on the quality of teaching and teaching, results in drop out, leads to understaffing of some school and over staffing of others. Several administrative strategies can be adopted to curb corruption in secondary schools in Nigeria.

\section{Recommendations}

The following suggestions are recommended for policy implement to help combat corruption in secondary education in Nigeria:

1. Public secondary school principals should encourage the formation of anti-corruption clubs in schools as a way of regularly bringing to the awareness of students and staff the dangers of corruption.

2. Principals should encourage debates and essay writings on corruption related topics in school in order to help sensitize staff and students about corruption and the evils associated with it.

3. Teachers and other stake holders should help in combating corruption in secondary schools by regularly teaching and promoting core values of integrity, hard work, responsibility, honesty and obedience.

4. Government should help schools to properly monitor examination by installing closed circuit television in secondary schools in the state.

5. Seminars and conferences on core values, corruption and ethical issues should regularly be organized in schools and experts be invited to give talks to staff and students.

6. Total and complete value re-orientation of the Nigerian society could help reduce the spread of corruption in secondary education.

\section{References}

Adebanjo, A. (2014). "Developing the right mindset: The mindset and attitude for achieving goals". Abuja: Accurate Press.

Adebayo, A. \& Obaje, A. F. (2016). Corruption in Nigeria: Bane to an effective realization of social studies educational objectives at the basic level of education. Spoleczens Two 1 Rodzina, 53(4), 71-92.

Aduhor, U. (2015). Analysis of ethical challenges and control measures among secondary school principals in Delta State. Unpublished M/ Ed Dissertation, Delta State University, Abraka, Nigeria. 
Akande, R. S. (2017). Corruption and state capacity in sub-Saharan African: A cross country analysis. International Journal of Economic, Commerce and Management, 5(4), 615-628. www.ijecm.co.uk/wp-content/uploads /2017/04/5440.pdf.

Amini-Philips, C., \& Chukwuma, O. C. (2017). Corruption and administration of higher education institutions in Nigeria. World Journal of Social Science, 4(2), 12-22. https://doi.org/10.5430/wjssv4n2p12.

Author. (2000). Examination malpractice in tertiary institutions in Nigeria. Unpublished Master Dissertation, Delta State University, Abraka.

Augusto, L. C. (2014). Six strategies to fight corruption. The World Bank Group. http://www.worldbank.org.

Asongo, S. A. (2013). Fighting corruption in Africa; do existing corruption-control levels matter? International Journal of Development Issues, 12, 35-52.

Babalola, J. B (2010). Transition from chalk board to digital white board: keeping pace with the challenges of $21^{\text {st }}$ century learning technologies in a developing economy. Journal of Educational Review, 3(2), 161-172.

Borcan, O., Lindahl, M. \& Mitrut, A. (2017). Fighting corruption in education: What works and who benefits? American Economic Journal Policy, 9(1), 180-209. https://doi.org/10.1257/pol.20150074. www.researchgate.net. s

Choe, C., Dzhumashev, R., Islam, A. and Khan, Z. H. (2013). The effect of informal networks on corruption in education: Evidence from household survey data in Bangladesh. The Journal of Development Studies, 49(2), 238-250. https://doi.org/10.1080/00220388.2012.709620

Delta State Ministry of Information (2013). "Mid-Term Report by the Hounorable Commissioner for Basic and Secondary Education" - Prof. Patrick Muoboghare. Hot News, Nigeria. Retrieved from www.deltastate.gov.en/index.php/template/mid-termreport\#August2o

Federal Government of Nigeria (2014). The National Policy on Education. Abuja: NERDC.

Ferraz, C., Finan, F. \& Moreira, D. B. (2012). Corrupting learning: Evidence from missing Federal education fund in Brazil. Journal of Public Economics, 96(9\&10), 712-726.doi.10.3386/w1815o.

Farzanegan, M. R. \& Witthuhn, S. (2016). Corruption and political stability: Does the youth bulge matter? European Journal of Political Economy, 49, 47-70. Retrieved from: https://www.sciencedirect.com/science/article/pii/So176268016303470. Accessed 26th July, 2018

Hallak, J. \& Poisson, M. (2002). Ethics and corruption in education: Policy Forum Number 15. Results from the expert Workshop held at the IIEP Paris, France. 28-29 November, 2001. Paris IIEP, UNESCO.

Justesen, M., K., \& Bjornskov, C. (2014). Exploiting the poor: Bureaucratic corruption and poverty in Africa. World Development, 58, 106-115. https://Doi:10.1016/j.worlddev.2014.01.002. Source: [Cross ref], [Web of Science], [GoogleScholar]. https://www.sciencedirect.com/science/article/abs/pii/So305750X1400o035

Meet, \& Narayan, L. (2014). Corruption in education- nature and causes. International Journal of Research, 1(8), 211-223.

Source: https://www.researchgate.net/publication/310461078_Corruption_in_Education_-_Nature_and_Causes

Nwankwo, B. C. \& Nweke, P. O. (2016). Effects of corruption on educational system: A focus on private secondary schools in Nsukka zone. Global Journal of Human Social Science: Arts and Humanities, 16(5), 59-67. Source:https://socialscienceresearch.org/indexphp/GJHSS/article/1834/1774.

Odeh, A. M. (2015). The effects of corruption on good governance in Nigeria. International Journal of Development and Sustainability, 4(3), 292-307.

Ogbonnaya, N. O. (2009). Social and political contexts of educational administration. Nsukka: Chuka Educational Publishers.

Okpechi, P. A, Denwigwe, C., Asuquo, P. N., Abuo, C., Unimna, F. U., \& Kolawole, O. N. (2018). Demographic variables and in-school adolescents' perception of corruption in Calabar, Nigeria. Asian Journal of Education and Social Studies, 2(2), 1-6. Doi:10.9734/AJESS/2018/41631.

Yadongha, S. (2013) Bayelsa State: Years of Neglect Cause Decay. Vanguard News. Special Report/Comments. December, 28

Suleiman, Y., Yusuf, A. A. \& Ibrahim, M. A.(2019). Addressing the factors responsible for schooling without learning in primary and secondary schools in Nigeria. International Journal of . International Journal of Synergy and Research, 7, 161-178,

Taaliu, S. T. (2017). Corruption in schools and universities in Kenya..Social Sciences, 5, 227-231.Source: http://www.scrip.org/journal/jss doi.org/10.4236jss.2017.54020.

The Premium Times, (2012). Delta State government suspends five students and other principals hammered for the disappearance of fifty KVA generators. May, 14

Transparency International Bangladesh (2001). Report card survey on the textbook crisis of the secondary school students. https://atositchallenge.net/wp-content/uploads/2016/11/Meier2oo4corruption-in-education.pdf.

Transparency International and African Education Watch (2010). Good governance lesson for anti corruption. www.transparency.org. 
Ugoani, J. N. N. (2016). Education corruption and teacher absenteeism in Nigeria. Independent Journal of Management and Production, 7(2), 546-566.

United Nations Convention against Corruption (2003). Statement on the adoption by UNCAC at United Nations 10 principles on corruption. http://www.unglobalcompact.org/aboutthegc/thetenprinciples/anti-corruption.html.

Whawo, D. D. (2015). Identifiable corrupt practices among staff and students of secondary schools in Delta State of Nigeria. International Journal of Secondary Education, 3(5), 50-54. DOI:10.11648/J.ijsedu.20150305.12

World Bank (2003). The anti-corruption in transition: A contribution to the policy debate. Washington, DC, World Bank. 